\title{
PERILAKU ORGANISASI DAN KEPEMIMPINAN \\ SEBAGAI SEBUAH SISTEM
}

Oleh: Fitriani

Dosen IAIN Bone

\begin{abstract}
In the last decade Islamic educational institutions have evolved as an increasingly complex institution that requires a well-ordered organization. The complexity of Islamic educational institutions is particularly evident from the need for management of educational implementation by management approach. That is the need to use management science approach in educational institutions especially Islamic educational institutions to be absolute. So the development of educational administration becomes an interesting part for practitioners and educational experts until now. In educational institutions, the relationships between leadership, management, administration and organization are mutually demanding and have an important role in advancing Islamic education institutions. Therefore, these four components can not be separated in educational institutions.
\end{abstract}

Kata Kunci: Organizational Behavior and Leadership

Organisasi merupakan kumpulan dari beberapa orang dan dapat dikatakan bahwa kelompok yang ada baik untuk semua orang atau kelompok dalam sebuah organisasi sudah pasti memiliki tujuan dan pandangan masingmasing dari kerjanya dalam organisasi. Mereka bersaing untuk mencapai kepentingannya masing-masing dalam organisasi tersebut. Hal ini juga ditandai dengan perbedaan yang ada mengenai segala macam sifat dalam 
anggota organisasi tersebut. Akan tetapi dalam sebuah organisasi ada seorang pimpinan yang mampu mengarahkan anggota organisasinya agar mampu mencapai tujuan bersama akan organisasi itu, terlepas dengan tujuan pribadi masing-masing anggota tersebut.

Maka dengan demikian, seorang pemimpin organisasi memiliki andil yang sangat besar dalam pencapaian tujuan organisasi secara efektif dan efesien. Pemimpinlah yang menentukan kemana organisasi mau dibawa dan bagaimana pergerakan semua elemen yang ada dalam organisasi agar dapat mencapai tujuan yang telah ditetapkan. Untuk mencapai tujuan itu tentu bukan perkara mudah, karena ada faktor manusia yang ada dalam organisasi yang seringkali memunculkan masalah yang rumit dan sulit dipecahkan dibanding masalah-masalah teknis.

\section{Perilaku Organisasi}

\section{a. Konsep Dasar Organisasi}

Setiap manusia akan berhubungan dengan bermacam-macam orang yang begitu kompleks dan bersangkutan dengan kebutuhan baik dari segi ekonomi, sosial, budaya, rekreasi, pendidikan dan lain sebagainya. Disadari atau tidak disadari, sengaja atau tidak disengaja, setiap manusia selalu berada, dibesarkan dalam dan menjadi anggota oeganisasi. Ini berlangsung sejak lahir hingga pada saat meninggal dunia.

Dalam perkembangan dunia yang begitu kompleks, begitu juga permasalahan manusia yang selalu berkembang dan begitu kompleks. Pada dasarnya manusia tidak bisa hidup sendiri dalam rangka memenuhi kebutuhan hidupnya, maka dengan adanya tujuan untuk memenuhi kebutuhan hidupnya tersebut, dengan demikian manusia 
membentuk suatu kelompok atau organisasi, entah apapun nama organisasinya. Sedangkan ciri utama dari peradaban manusia dalam masyarakat adalah keterlibatannya dalam sebuah organisasi tertentu. Oleh karena itu, manusia adalah pendukung utama dari setiap organisasi. Perilaku manusia yang berada dalam organisasi itulah awal dari perilaku organisasi itu sendiri. ${ }^{1}$

Menurut Baharuddin dalam bukunya menyatakan bahwa Organisasi diartikan sebagai wadah untuk menjalin kerja sama yang baik diantara para individu. Bahkan dikatakan pula bahwa organisasi telah lama dikenal oleh manusia bahkan ia muncul semenjak manusia pertama ada. $^{2}$

Selain itu, organisasi adalah suatu usaha untuk mempermudah pemenuhan kebutuhan dengan membentuk hubungan kerja sama dengan membuat kelompok-kelompok. Tujuan dari usaha manusia akan lebih mudah dicapai dan diperoleh dengan cara bersama-sama daripada seorang diri. Maka dengan demikian, bisa dikatakan bahwa organisasi adalah wadah yang memungkinkan masyarakat dapat meraih hasil yang sebelumnya tidak dapat dicapai oleh individu secara sendiri-sendiri. Organisasi merupakan suatu unit yang terkoordinasi yang terdiri setidaknya dua orang, yang berfungsi mencapai sasaran tertentu atau serangkaian tertentu. ${ }^{3}$

Istilah organisasi mempunyai dua pengertian umum. Pertama organisasi diartikan sebagai suatu lembaga atau kelompok fungsional,

\footnotetext{
${ }^{1}$ Veitzhal Rivai \& Deddy Mulyadi, Kepemimpinan dan Perilaku Organisasi (Jakarta: RajaGrafindo Persada, 2011), h. 169.

${ }^{2}$ Baharuddin \& Umiarso, Kepemimpinan Pendidikan Islam (Jogjakarta: Ar-Ruzz Media, 2012), h. 121.

${ }^{3}$ Veitzhal Rivai \& Deddy Mulyadi, Kepemimpinan dan Perilaku Organisasi h. 170.
} 
misalnya, sebuah perusahaan, sebuah sekolah, sebuah perkumpulan dan badan pemerintahan. Kedua, merujuk kepada proses pengorganisasian yaitu bagaimana pekerjaan diatur dan dialokasikan di antara para anggota, sehingga tujuan organisasi itu dapat tercapai secara efektif. Sedangkan organisasi itu sendiri diartikan sebagai kumpulan orang dengan sistem kerja sama untuk mencapai tujuan bersama.

Berkaitan dengan pengertian organisasi di atas. Dalam hal ini sejalan dengan apa yang difirmankan Allah swt dalam QS Al Hujurat/49: 10 yang berbunyi: ${ }^{4}$

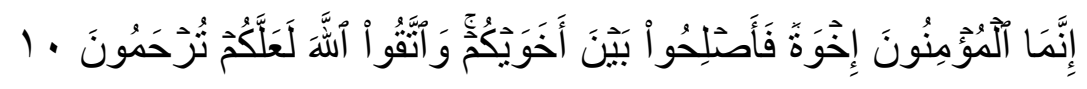

Sesungguhnya orang-orang yang beriman itu bersaudara. Karena itu maka damaikanlah antara kedua saudaramu dan bertakwalah kepada Allah swt. supaya kamu mendapat rahmat.

Dengan demikian, Islam juga mengajarkan bahwa hidup ini tidak bisa dijalani dengan seorang diri. Karena orang tidak akan mampu hidup secara wajar tanpa adanya orang lain. Penting menyadari bahwa ada orang lain selain dirinya sendiri dalam kehidupan ini. Dengan kesadaran itu, maka ia akan teringat hak dan kepentingan diri orang lain, sehingga teringat pula bahwasanya ada kewajiban pada dirinya yang harus ditunaikan kepada orang lain. Pada akhirnya, kesadaran yang semacam ini mampu menjadikan seseorang menjadi penting bagi orang lain, begitu pula sebaliknya. Ia tidak akan mampu menyelesaikan tugas-tugas dan kewajibannya dengan baik,

\footnotetext{
${ }^{4} \mathrm{Al}$ Quran dan Terjemahnya, Departemen Agama Republik Indonesia (Surabaya: Al Hidaya, 2002), h. 846.
} 
tanpa bantuan orang lain. Oleh karena itu, manusia itu lemah dengan dirinya sendiri dan menjadi kuat dengan bersama orang lain. ${ }^{5}$

Maka menurut hemat penulis, dari uraian di atas dapat dikatakan bahwa organisasi adalah wadah dari sebuah proses penentuan, pengelompokkan dan penyusunan berbagai macam kegiatan dengan melibatkan orang-orang yang menjadi anggota dalam organisasi tersebut untuk mencapai tujuan tertentu.

b. Konsep Perilaku

Pengertian perilaku dapat dibatasi sebagai keadaan jiwa untuk berpendapat, berfikir, bersikap, bertindak dan lain sebagainya, yang merupakan refleksi dari berbagai macam aspek, baik fisik maupun non fisik. Perilaku juga diartikan sebagai suatu reaksi psikis seseorang terhadap lingkungannya, reaksi yang dimaksud digolongkan menjadi 2, yakni dalam bentuk pasif (tanpa tindakan nyata atau konkrit), dan dalam bentuk aktif (dengan tindakan konkrit), Sedangkan dalam pengertian umum perilaku adalah segala perbuatan atau tindakan yang dilakukan oleh makhluk hidup. ${ }^{6}$

Dalam ensiklopedia Amerika disebutkan bahwa perilaku diartikan sebagai suatu aksi dan reaksi organisme terhadap lingkungannya. Untuk menimbulkan reaksi maka diperlukan rangsangan. Jadi rangsangan tertentu akan menghasilkan reaksi atau perilaku tertentu. ${ }^{7}$ Dengan demikian perilaku individu dapat ditentukan

\footnotetext{
${ }^{5}$ Ahmad Djalaluddin, Manajemen Qur'ani Menerjemahkan Idarah Ilahiyah dalam Kehidupan (Malang: UIN-Malang Press, 2007), h. 146.

${ }^{6}$ Soekidjo Notoatmodjo, Pendidikan dan Perilaku Kesehatan (Jakarta: Rineka Cipta, 2003), h. 25.

${ }^{7}$ Perilaku seseorang dikelompokkan ke dalam perilaku wajar, perilaku dapat diterima, perilaku aneh, dan perilaku menyimpang. Dalam sosiologi, perilaku dianggap sebagai sesuatu yang tidak ditujukan kepada orang lain dan oleh karenanya merupakan
} 
oleh berbagai macam ransangan yang ada disekitarnya, dalam artian seluruh perilaku yang menjadi tabiat manusia tidak hanya ditentukan oleh bawaan dari lahir/fitrah manusia tersebut dalam aliran psikologi disebut dengan nativisme semata, akan tetapi juga dipengaruhi oleh lingkungan (empirisme), bahkan pula ditentukan oleh aspek geografis latar belakang orang tersebut.

Sedangkan menurut pandangan Behavioristik diartikan bahwa perilaku sebagai respon terhadap stimulus akan sangat ditentukan oleh keadaan stimulusnya dan individu seakan-akan tidak mempunyai kemampuan untuk menentukan perilakunya.

Sedangkan menurut Skinner yang dikutip Notoatmodjo menyatakan bahwa perilaku merupakan hasil hubungan antara perangsang (stimulus dan tangapan atau respon). Ia membedakan ada dua respon, yaitu: ${ }^{8}$

1) Respondent Respons atau Reflexive Respons, merupakan respon yang ditimbulkan oleh rangsangan tertentu. Respon ini sangat terbatas keberadaannya pada manusia karena hubungan yang pasti antara stimulus dan respon kemungkinan untuk memodifikasinya sangat kecil.

2) Operant Respons atau Instrumen Respons, merupakan respon yang timbul dan berkembangnya diikuti oleh perangsang tertentu.

suatu tindakan sosial manusia yang sangat mendasar. Perilaku tidak boleh disalah artikan sebagai perilaku sosial, yang merupakan suatu tindakan dengan tingkat lebih tinggi, karena perilaku sosial adalah perilaku yang secara khusus ditujukan kepada orang lain. Penerimaan terhadap perilaku seseorang diukur relatif terhadap norma sosial dan diatur oleh berbagai kontrol sosial. Dalam kedokteran perilaku seseorang dan keluarganya dipelajari untuk mengidentifikasi faktor penyebab, pencetus atau yang memperberat timbulnya masalah kesehatan. Intervensi terhadap perilaku seringkali dilakukan dalam rangka penatalaksanaan yang holistik dan komprehensif. Perilaku manusia dipelajari dalam ilmu psikologi, sosiologi, ekonomi, antropologi dan kedokteran.

${ }^{8}$ Soekidjo Notoatmodjo, Pendidikan dan Perilaku h. 37. 
Respon ini merupakan bagian terbesar dari perilaku manusia dan kemungkinan untuk memodifikasinya sangat besar bahkan tak terbatas.

Menurut hemat penulis, dapat dikatakan bahwa perilaku individu pada diri manusia tidak timbul dengan sendirinya, tapi itu adalah reaksi dari stimulus yang terjadi, baik secara internal maupun secara eksternal. Dan hal ini tidak terlepas dari sebuah proses kematangan organ-organ tubuh. Lebih dari sekedar itu, perilaku individu tersebut dapat berupa baik yang bisa diamati maupun tidak bisa diamati.

c. Pengertian Perilaku Organisasi

Perilaku organisasi adalah suatu studi yang menyangkut aspekaspek tingkah laku manusia dalam suatu kelompok tertentu. Hal ini dapat meliputi aspek yang ditimbulkan oleh pengaruh organisasi terhadap manusia demikian pula halnya pengaruh manusia terhadap organisasi. Tujuan akan telaah ini adalah sebuah usaha untuk mendeterminasi pengaruh manusia terhadap pencapaian tujuan-tujuan organisasi. ${ }^{9}$

Perilaku organisasi (organizational behavior) adalah sebuah bidang studi yang menyelidiki pengaruh yang dimiliki oleh individu, kelompok, dan struktur terhadap perilaku dalam organisasi, yang bertujuan menerapkan ilmu pengetahuan semacam ini guna meningkatkan keefektifan sebuah organisasi. ${ }^{10}$ Disamping itu juga disebutkan bahwa dalam perilaku organisasi terjadi interaksi dan hubungan antara organisasi di satu pihak dan perilaku individu di lain

\footnotetext{
${ }^{9}$ Veitzhal Rivai \& Deddy Mulyadi, Kepemimpinan dan Perilaku Organisasi h. 171.
}

${ }^{10}$ Khairul Maulana, Resume Perilaku Organisasi, (Makalah Sekolah Tinggi Manajemen Informatika dan Komputer STMIK Mercusuar, 2010), h. 7. 
pihak. Kesemuanya ini memiliki tujuan praktis yaitu untuk mengarahkan perilaku manusia untuk mencapai tujuan-tujuan bersama sesuai dengan tujuan organisasi.

Jadi sebenarnya dalam analisis penulis, bahwa perilaku organisasi adalah perilaku individu dalam anggota organisasi yang saling mempengaruhi satu sama lain, sehingga tujuan bersama yang diupayakan mampu terealisasikan dengan baik.

\section{Kepemimpinan}

1. Konsep Dasar Kepemimpinan

Kepemimpinan dipahami sebagai segala daya dan upaya bersama untuk menggerakkan semua sumber dan alat (resources) yang tersedia dalam suatu organisasi. Untuk itu dapat dikatakan bahwa sukses tidaknya suatu organisasi untuk mencapai tujuan yang telah ditetapkan sengat tergantung atas kemampuan pempinannya untuk menumbuhkan iklim kerja sama agar dengan mudah dapat menggerakkan sumber daya tersebut, sehingga dapat mendayagunakannya dan dapat berjalan secara efektif dan efisien.

Di dalam lingkungan masyarakat atau di dalam organisasi, kepemimpinan terjadi melalui dua bentuk, yaitu: kepemimpinan formal (formal leadership) dan kepemimpinan informal (informal leadership). Kepemimpinan formal terjadi apabila di lingkungan organisasi jabatan otoritas formal dalam organisasi tersebut diisi oleh orang-orang yang ditunjuk atau dipilih melalui proses seleksi. Sedangkan kepemimpinan informal terjadi, dimana kedudukan pemimpin dalam suatu organisasi diisi oleh orang-orang yang muncul dan berpengaruh terhadap orang lain karena kecakapan khusus atau berbagai sumber yang dimilikinya 
dirasakan mampu memecahkan persoalan organisasi serta memenuhi kebutuhan dari anggota organisasi yang bersangkutan. ${ }^{11}$

Dalam ajaran Islam juga disebutkan bahwasanya Allah swt. menciptakan manusia di muka bumi adalah sebagai pemimpin (khalifah), sebagaimana firman Allah swt. dalam QS Al Baqarah/2:30 yang berbunyi: ${ }^{12}$

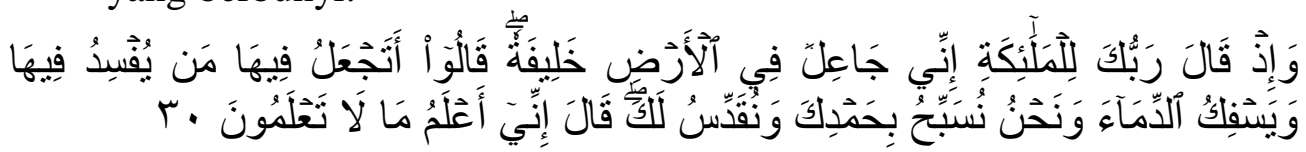

Dan ingatlah ketika Tuhanmu berfirman kepada para Malaikat: "sesungguhnya Aku hendak menjadikan seorang khalifah di muka bumi". Mereka berkata: "Mengapa Engkau hendak menjadikan (khalifah) di bumi itu orang yang akan membuat kerusakan padanya dan menumpahkan darah, padahal kami senantiasa bertasbih dengan memuji Engkau dan mensucikan Engkau?" Tuhan berfirman: "Sesungguhnya Aku mengetahui apa yang tidak kamu ketahui".

Dalam berbagai macam literatur disebutkan bahwa definisi tentang kepemimpinan bervariasi, sebanyak orang yang mencoba mendefinisikannya. Secara luas, kepemimpinan dapat didefinisikan yakni usaha atau proses untuk mempengaruhi dalam menentukan tujuan organisasi, memotivasi perilaku pengikut untuk mencapai tujuan, mempengaruhi untuk memperbaiki kelompok dan budayanya. Terkadang ia diartikan atau dipahami sebagai kekuatan untuk menggerakkan dan mempengaruhi orang. ${ }^{13}$ Dengan demikian, ia merupakan alat atau sarana untuk membujuk orang agar bersedia melakukan sesuatu dengan sukarela/sukacita.

\footnotetext{
${ }^{11}$ Wahjosumidjo, Kepemimpinan Kepala Sekolah, Tinjauan Teoritik dan Permasalahannya (Jakarta: RajaGrafindo Persada, 2005), h. 84.

${ }^{12} \mathrm{Al}$ Quran dan Terjemahnya, Departemen Agama Republik Indonesia h. 13

${ }^{13}$ Veitzhal Rivai \& Deddy Mulyadi, Kepemimpinan dan Perilaku Organisasi h. 2.
} 
Jadi menurut hemat penulis, dari beberapa pengertian kepemimpinan diatas disimpulkan bahwa kepemimpinan adalah sebuah usaha untuk mempengaruhi, memotivasi dan mengorganisir agar orang lain mau diajak untuk bekerja sama untuk mencapai tujuan bersama.

2. Kepemimpinan Pendidikan

Istilah kepemimpinan pendidikan mengandung dua pengertian, dimana kata pendidikan menerangkan di lapangan apa dan di mana kepemimpinan itu berlangsung, dan sekaligus menjelaskan pula sifat dan ciri-ciri kepemimpinan, yaitu bersifat mendidik dan membimbing. Sebagaimana kata pendidikan yang menunjukkan arti yang dapat dilihat dari dua segi, yaitu: ${ }^{14}$

1) pendidikan sebagai usaha atau proses pendidik dan mengajar seperti yang dikenal sehari-hari

2) pendidikan sebagai ilmu pengetahuan yang membahas berbagai masalah tentang hakikat dan kegiatan mendidik mengajar dari zaman ke zaman atau yang membahas prinsip-prinsip dan pratikpraktik mendidika dan mengajar dengan segala cabang-cabangnya yang telah berkembang begitu luas dan mendalam.

Dari dua hal tersebut, maka dapat penulis jelaskan bahwa kepemimpinan pendidikan pada dasarnya terdapat dan berperan pada usaha-usaha yang berhubungan dengan proses mendidik dan mengajar di satu pihak, dan pada pihak lain berhubungan dengan usaha-usaha pengembangan pendidikan sebagai satu ilmu dengan segala cabangcabangnya dan ilmu-ilmu pembantu lainnya.

\footnotetext{
${ }^{14}$ Marno, Triyo Supriyatno, Manajemen dan Kepemimpinan Pendidikan Islam (Bandung: Refika Aditama, 2008), h. 32.
} 
Kepemimpinan dalam lembaga pendidikan sangat berperan penting dalam mengembangkan seluruh sumber daya yang ada termasuk sumber daya manusia (SDM), oleh karena itu, para pakar pendidikan mencoba mengartikan kepemimpinan pendidikan, yaitu:

1) Nawawi mengatakan bahwa kepemimpinan pendidikan adalah proses menggerakkan, mempengaruhi, memberikan motivasi, dan mengarahkan orang-orang di dalam organisasi atau lembaga pendidikan tertentu untuk mencapai tujuan yang telah dirumuskan sebelumnya. Untuk mewujudkan tugas terebut, setiap pimpinan pendidikan harus mampu bekerja sama dengan orang-orang yang dipimpinnya untuk memberikan motivasi agar melakukan pekerjaannya secara ikhlas. ${ }^{15}$

2) Fachrudi mengatakan bahwa kepemimpinan pendidikan adalah suatu kemampuan dalam proses mempengaruhi, mengkoordinir orang-orang lain yang ada hubungannya dengan ilmu pendidikan dan pelaksanaan pendidikan dan pengajaran, agar kegiatan-kegiatan yang dijalankan dapat berlangsung lebih efisien dan efektif di dalam pencapaian tujuan-tujuan pendidikan dan pengajaran.

3) Sedangkan Assosiation of Supervision and Curiculum Development (ASCD), menyatakan bahwa kepemimpinan pendidikan adalah tindakan atau tingkah laku di antara individu-individu dan kelompok-kelompok yang menyebabkan mereka bergerak kea rah tercapainya tujuan-tujuan pendidikan yang menambahkan penerimaan bersama bagi mereka. ${ }^{16}$

\footnotetext{
${ }^{15}$ Marno, Triyo Supriyatno, Manajemen dan Kepemimpinan h. 32.

${ }^{16}$ Marno, Triyo Supriyatno, Manajemen dan Kepemimpinan h. 33
} 
Dari beberapa pendapat tersebut di atas, tentang pengertian kepemimpinan pendidikan, maka dapat penulis simpulkan bahwa yang dimaksud dengan kepemimpinan pendidikan adalah kemampuan seseorang dalam mempengaruhi, mengkoordinir, menggerakkan, memberikan motivasi dan mengarahkan orang-orang dalam lembaga pendidikan agar pelaksanaan pendidikan dapat lebih efisien dan efektif dalam mencapai tujuan-tujuan pendidikan yang telah dirumuskan.

Pemimpin pada hakikatnya adalah seseorang yang mempunyai kemampuan untuk mempengaruhi perilaku orang lain di dalam kerjanya dengan menggunakan kekuasaan. Kekuasaaan adalah kemampuan untuk mengarahkan dan mempengaruhi bawahan sehubungan dengan tugas-tugas yang harus dilaksanakannya. Semakin banyak jumlah sumber kekuasaan yang tersedia bagi pemimpin, maka makin besar potensi kepemimpinan yang efektif. ${ }^{17}$ Dengan demikian, penulis beranggapan bawah makin efektifnya kepemimpinan seseorang, maka kesuksesan dalam mencapai cita-cita semakin terbuka lebar. Dalam hal ini, seorang pemimpin benar-benar mampu mempengaruhi bawahnnya dalam melaksanakan tugas-tugasnya.

Dari pemaparan di atas tentang perilaku organisasi dan kepemimpinan, dapat penulis rangkum bahwa dalam sebuah organisasi pasti memerlukan orang yang mampu memimpin dengan baik yang mampu mengarahkan seluruh anggota dalam organisasi tersebut, sehingga memiliki persepsi yang sama akan tujuan bersama yang ingin dicapai. Dengan demikian, perilaku setiap individu yang terdapat dalam organisasi terarah dengan tujuan yang diinginkan. Maka suatu perilaku dalam

\footnotetext{
${ }^{17}$ Nanang Fattah, Landasan $\quad$ Manajamen $\quad$ Pendidikan (Bandung: Remaja Rosdakarya, 2009), h. 88.
} 
organisasi dan kemampuan pemimpin untuk memimpin sebuah organisasi terutama dalam lembaga pendidikan, hal tersebut menjadi sebuah sistem yang harus dijalankan oleh setiap komponen dalam organisasi tersebut.

\section{A. Simpulan}

Dalam sebuah organisasi pasti memerlukan orang yang mampu memimpin dengan baik yang mampu mengarahkan dan mengelola seluruh anggota dalam organisasi tersebut, sehingga memiliki persepsi yang sama akan tujuan bersama yang ingin dicapai. Dengan demikian, perilaku setiap individu yang terdapat dalam organisasi terarah dengan tujuan yang diinginkan. Maka suatu perilaku dalam organisasi dan kemampuan pemimpin untuk memimpin sebuah organisasi terutama dalam lembaga pendidikan, hal tersebut menjadi sebuah sistem yang harus dijalankan oleh setiap komponen dalam organisasi tersebut.

\section{DAFTAR RUJUKAN}

Al Quran dan Terjemahnya, Departemen Agama Republik Indonesia Surabaya: Al Hidaya, 2002.

Baharuddin \& Umiarso. Kepemimpinan Pendidikan Islam. Jogjakarta: ArRuzz Media, 2012

Djalaluddin, Ahmad. Manajemen Qur'ani Menerjemahkan Idarah Ilahiyah dalam Kehidupan. Malang: UIN-Malang Press. 2007

Fattah, Nanang. Landasan Manajamen Pendidikan. Bandung: Remaja Rosdakarya. 2009

Marno, Triyo Supriyatno, Manajemen dan Kepemimpinan Pendidikan Islam Bandung: Refika Aditama, 2008

Maulana, Khairul. Resume Perilaku Organisasi, Makalah Sekolah Tinggi Manajemen Informatika dan Komputer STMIK Mercusuar, 2010

Notoatmodjo, Soekidjo. Pendidkan dan Perilaku Kesehatan, Jakarta: Rineka Cipta, 2003 
Rivai Veitzhal \& Deddy Mulyadi. Kepemimpinan dan Perilaku Organisasi, Jakarta: RajaGrafindo Persada, 2011

Wahjosumidjo. Kepemimpinan Kepala Sekolah, Tinjauan Teoritik dan Permasalahannya, Jakarta: RajaGrafindo Persada, 2005 